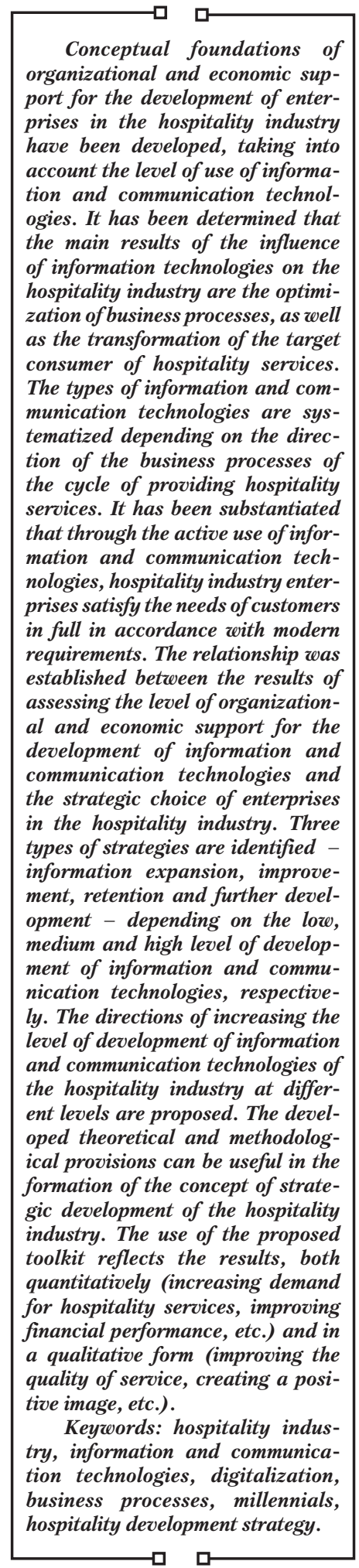

\title{
IMPROVING THE ORGANIZATIONAL AND ECONOMIC SUPPORT FOR THE DEVELOPMENT OF ENTERPRISES IN THE HOSPITALITY INDUSTRY IN THE USE OF INFORMATION AND COMMUNICATION TECHNOLOGIES
}

\section{Iryna Petrovska}

Corresponding author

$\mathrm{PhD}$, Associate Professor, Head of Department Department of Hospitality Industry and Sustainable Development*** E-mail: petroirinaolegovna@gmail.com

OIha Safronova Associate Professor Department of Regional Policy* Olena Mital

$\mathrm{PhD}$, Associate Professor Department of Hospitality Industry andSustainable Development*** Natalia 0 metsyns a Associate Professor Department of General Engineering Disciplines and Heat Power Engineering*** Volody y r Moroz Associate Professor

Department of Regional Policy*

Oksana Vidomenko PhD, Associate Professor Department of Economics and Law National University of Food Technologies Volodymyrska str., 68, Kyiv, Ukraine, 01601

Iryna Le bedyne t s Senior Lecturer

Department of Marketing, International Economics andBusiness Administration Academician Yuriy Bugay International Scientific and Technical University, Higher Educational Institution Magnitogorsky lane, 3, Kyiv, Ukraine, 02000

Yuli a Maistrenko

PhD, Associate Professor**

Antonina Shostakovska

Doctor of Economic Sciences, Associate Professor, Head of Department**

Oleksandr Nosyriev $\mathrm{PhD}$, Associate Professor Department of International Business and Finance National Technical University "Kharkiv Polytechnic Institute" Kyrpychova str., 2, Kharkiv, Ukraine, 61002

* Educational and Scientific Institute of Public Administration and Civil Service Taras Shevchenko National University of Kyiv Volodymyrska str., 60, Kyiv, Ukraine, 01033 ** Department of Management and Marketing European University Akademika Vernadskoho blvd., 16-V, Kyiv, Ukraine, 02000 *** Tavriya National University named after V. I. Vernadsky Dzhona Makkeina str., 33, Kyiv, Ukraine, 01042
Received date 11.11.2021 Accepted date 14.12.2021 Published date 28.12.2021
How to Cite: Petrozska, I., Safronova, O., Mital, O., Ometsynska, N., Moroz, V., Vidomenko, O., Lebedynets, I., Maistrenko, A., Shostakovska, Y., Nosyriev, O. (2021). Improving the organizational and economic support for the development of enterprises in the hospitality industry in the use of information and commu-

nication technologies. Eastern-European Journal of Enterprise Technologies, 6 (13 (114)), 29-38. doi: https://doi.org/10.15587/1729-4061.2021.247943

\section{Introduction}

In the context of the global development of information technologies and the digitalization of the economy, there is a transformational transformation of the interests and mo- tives of the behavior of economic entities in the direction of coordinated interaction. The result of the use of information and communication technologies is an increase in labor productivity due to information support of the decision-making system, which provides economic entities with additional 
competitive advantages. At the beginning of the twentieth century, the active use of information and communication technologies was inherent only in certain innovative types of activity. In turn, the era of the digital economy has formed the so-called new development paradigm that embraces all, without exception, types of economic activity. The hospitality industry has experienced the most tangible impact from the development of a global informatization business, as a result of which meaningful changes in business processes have occurred. In this regard, information trends have become the determining factors in the development of enterprises in the hospitality industry [1]. Using information and communication technologies, consumers of hospitality services get an additional set of opportunities. For example, they can create a tour, book it, choose a convenient flight, buy tickets, and, if necessary, book a hotel room at transfer points. It is also possible to arrange a car rental in places of rest, order tickets for entertainment or sports events. In addition to consumer benefits, information and communication technologies create the basis for an effective management system for enterprises in the hospitality industry, using information systems of various levels of complexity. Among the many types of information systems, the most widespread are the management systems of a travel company, a restaurant, a hotel, a sanatorium, a cultural and entertainment center, etc. Information systems are associated with an absolute manager who, unlike a person, performs all tasks correctly, accurately and on time. It manages all processes of the enterprise, turning it into a reliable business machine, freeing specialists from routine work and providing them with information support for making management decisions [2]. An equally important role is played by modern means of communication and communication: IP-telephony, cellular, satellite and trunked communication systems, Wi-Fi and Bluetooth wireless technology. In addition, multimedia technologies claim a leading role in modern conditions. In this regard, it seems appropriate to establish an objective relationship between the use of information and communication technologies and the strategic directions of development of enterprises in the hospitality industry.

\section{Literature review and problem statement}

The intensification of digital transformation processes has changed the approaches to researching the problems of developing enterprises in the hospitality industry, focusing on the effectiveness of information and communication technologies (ICT).

The work [3] presents the generalized results of the analysis of the use of ICT in the field of hotel management. It is emphasized that the activities of hotels depend on ICT both in the field of internal management and in building relationships with customers and other stakeholders. This research is useful for both researchers and hotel managers in terms of exploring new trends in the ICT field. It should be noted that the study summarizes the experience of past years and does not contain modern innovative schemes for the introduction of ICT in certain segments of the hospitality industry. This problem is solved in the study [4], which defines the role of ICT in creating the attractiveness of a destination and considers the consequences of the development of the tourism sector in the direction of a reasonable destination. The focus is on identifying and analyzing technological solutions, taking into account the six elements that shape the attractiveness of a tourist destination, namely attractions, public and private amenities, accessibility, human resources, image, character and prices. It is concluded that as a result of the use of ICT in the hospitality industry, labor productivity, profitability and quality of services are increased. In addition, ICTs facilitate decision-making, influence the overall travel experience, and enable the sharing of visitor experiences through Internet dissemination channels and information accessibility. The main value of work lies in establishing the relationship between ICT and the innovativeness of marketing and management of tourism destinations. But the issues of creating competitive advantages as a result of the use of ICT remained unresolved. It is this approach that takes place in [5], the purpose of which is to study the influence of IT capabilities on the competitiveness of hotels. The hypothesis is put forward and proved that the costs of IT work, IT systems and IT sites have different effects on the competitiveness of hospitality enterprises. The practical implications of the study are to use financial data to obtain direct measurements of individual IT capabilities and to determine the individual impact of IT capabilities on the competitiveness of hotels. The limitation of this study lies in the general approach to considering IT capabilities. This requires further detailing in the direction of studying specific ICT tools and their impact on the business processes of enterprises in the hospitality industry.

In this regard, studies are of interest, in which the authors focus on certain ICT tools, or business processes, which it seems advisable to improve. Yes, scientists devote many works to artificial intelligence technologies. The study [6] developed a theoretical basis for assessing the impact of artificial intelligence on the level of attraction, retention and productivity of employees, which, as a result, affects the quality of service and customer satisfaction. A somewhat different side of the use of artificial intelligence is highlighted in the work [7]. The hospitality and tourism industry faces a number of workforce challenges, especially with high employee turnover and associated replacement costs, with the constant search and recruitment of new workers. The goal of [7] is to discuss how hospitality and tourism organizations can use electronic human resource management and artificial intelligence. These technologies help to recruit and select qualified employees, increase the level of maintenance of individuals and reduce the time required to replace employees. A conceptual framework for the adoption of service robots by customers, employees, which will help determine corporate decision-making in the workplace, is contained in the study [8]. At the same time, the works under consideration lack financial aspects of the effectiveness of the use of these ICT tools. This may be due to the difficulty in quantifying them. Therefore, it is advisable to focus future research on the creation of added value by artificial intelligence and service works implemented in existing hospitality enterprises.

The emergence of new ICT tools requires further research in this direction. All this allows to assert the relevance of the article [9], which considers the development of wireless technologies in tourism and hospitality, since 2000. Wireless technologies are a set of ICTs, including radio transmission (for example, mobile or satellite technologies), widely used in tourism and hospitality, but which have not yet been comprehensively studied. Unlike previous studies, 
the authors use both a quantitative and a qualitative approach in defining the role of these technologies in supporting tourism and hospitality.

At the present stage, considerable attention is paid to the development of the hospitality industry in the context of COVID-19. This led to the development of scientific research in this area. In particular, the public's perception of robotic services against the background of COVID-19 was investigated, which made it possible to develop certain practical proposals [10]. But the issues of investment attractiveness of this ICT tool remained unclear. The solution to this problem is contained in [11], which proposes a policy for the operation of multi-seat robots for room service traveling within the hotel. The study concluded that because multi-capacity jobs can serve many requests in a single trip, this operating policy can reduce the investment cost of operating the robots. The value of the proposed ideas is that after the outbreak of COVID-19, people avoid face-to-face contact, so there is a growing interest in contactless services through the introduction of workable services.

The active use of social networks and instant messengers also has an impact on the development of the hospitality industry. The goal of [12] is to apply the theory of parasocial relations to increase awareness of the relationship between the hospitality brand and the consumer in social networks. A study [13] examines the effectiveness of communication about persistence in social networks. In other words, what impact do social media posts have on the perception of environmental corporate social responsibility and the intention to choose an environmentally friendly hotel. It also suggests the feasibility of using Instagram as a tool to identify these differences in the behavior of tourists, segmenting them by article, as well as by topics whether they traveled alone or with other people [14]. This study opens up the possibility of using Instagram as a tool to identify various forms of tourist behavior. Another confirmation that the hospitality industry is actively using ICT to study consumer behavior is the work [15], which investigated online shopping among young people. Experienced travelers have shared their hotel service reviews that are helpful for budding travelers to help them decide when to book a hotel. In the digital world, many researchers are focusing their efforts on identifying various factors that influence travelers' online hotel booking intent. Thus, in [16], an analysis of information is carried out that can be useful and significant when choosing a particular hotel. The emphasis is on the fact that hotel managers need to monitor negative reviews and take certain measures to overcome these problems. The authors of the article suggest that hoteliers focus on service quality, which will help them make their customers happy and encourage them to upload positive reviews. It should be noted that there will always be clients who will have complaints about a particular hotel, so this problem will remain unresolved. In a study [17], to eliminate it, it is proposed to establish a feedback between online customer reviews and employee response to reviews. This will allow future consumers to make a more informed decision about choosing a hotel.

To improve the quality of services and competitiveness, as well as adapt to global trends in technology, more and more scientists are thinking about integrating innovative technological equipment and service modes in the catering industry. Thus, the influence of the interactive table on the satisfaction of consumers from the order and the intention of the return visit was determined. The re- sults of this study showed that consumers can enjoy using a digital machine to fulfill an order, which affects their willingness to return [18].

The adoption of the Internet of Things is a great factor in the hospitality industry, fostering the integration of the digital and real world. [19] explores the practical applications of the Internet in hospitality to help identify opportunities and challenges for technology adoption to create competitive advantage and improve service delivery.

It should be noted that in recent years, the study of the profile of tourists is gaining popularity in scientific works. Thus, after reviewing some of the most interesting studies of Millennials and Post Millennials, [20] presents the results of an online empirical survey conducted on a sample of 200 Internet users. The questionnaire, used through a computerized web interview system, consists of structured questions about practices, attitudes, emerging needs, and the use of new technologies that characterize millennials and post millennials, with a particular focus on tourism.

The article [21] aims to explore how hoteliers are using mobile technology to shape services that enable customers to create their own unique and personalized experience. The results provide a full description of mobile value co-creation in the context of a hotel. Similar results are contained in the study [22].

It is worth noting that with the help of ICT in the hospitality industry, it is possible to predict the demand for certain services, to obtain useful information for the development and adoption of an adequate decision.

The generalization of the above information indicates a certain degree of limitation of the existing approaches to the study of the development of enterprises in the hospitality industry in the context of the use of information and communication technologies:

- the lion's share of ICT in the hospitality industry is associated with social networks and mobile devices, other tools that help improve the efficiency of the development of hospitality enterprises through customer satisfaction. However, there is little ICT research affecting hotel personnel development;

- a large number of studies focus on certain regional aspects of ICT implementation of individual ICTs, characterize one or more tools, or optimized business processes. However, a small number of researchers investigate ICT in a comprehensive manner and by influencing the development strategy of hospitality enterprises.

\section{The aim and objectives of research}

The aim of research is to improve the organizational and economic support for the development of enterprises in the hospitality industry in the context of the use of information and communication technologies. This will allow to determine the mutual influence of the components of this process and choose the most effective strategy.

To achieve the set aim, the following objectives were solved:

- to study modern global information trends that accelerate or slow down the development of the hospitality industry;

- to analyze the prerequisites for the implementation and types of information and communication technologies affecting the development of the hospitality industry; 
- to establish the relationship between the use of the species diversity of information and communication technologies and the optimization of the processes and functions of enterprises in the field of hospitality;

- to determine the procedure for choosing a strategy for the development of enterprises in the hospitality industry on the basis of a schematic reflection of the process of improving the organizational and economic support for the development of enterprises in the hospitality industry in the context of the use of information and communication technologies.

\section{Materials and methods of research}

The theoretical and methodological basis of the research was made up of the main provisions of the theory of development, the concept of the digital economy, theoretical and methodological developments of modern scientific schools in the field of management and administration, as well as individual scientists.

In the process of research, a complex of general scientific, specifically scientific and special methods of cognition was applied. A logical method was used to substantiate the feasibility of using information and communication technologies in the development of enterprises in the hospitality industry. Theoretical generalization and formulation of conclusions was carried out using the abstract-logical method. System analysis is used to study information trends and factor prerequisites for the development of the hospitality industry. Using the method of comparative analysis, the conditions for the use of information and communication technologies were compared. The graphical method was used to visualize and structure individual research questions. The calculation of the absolute and relative indicators for assessing the world data of Internet users was made using the statistical method. To classify information and communication technologies, the method of systemic generalization was used. Establishing the relationship between the volume of ICT output and the profitability of the objects of the Ukrainian hospitality industry was carried out using regression analysis (pair regression).

The information base of the study is the official data of the State Statistics Service of Ukraine, data from international reports on digitalization and informatization, as well as the development of the hospitality industry. In addition, monographs and periodicals on the topic of research, as well as the authors' own research were used.

\section{Results of studies of the impact of information and communication technologies on the effectiveness of the development of enterprises in the hospitality industry}

\section{1. Research of global information trends in the de-} velopment of the hospitality industry

In modern conditions of digital globalization, the development of all sectors of the economy and public life is actively influenced by information and communication technologies. The analysis of the experience of using ICT proves that the most noticeable transformational technological transformations among other types of economic activity were observed at the enterprises of the hospitality industry. This is primarily due to the fact that the sphere of hospitality (travel and tourism, accommodation, food, recreation and leisure), in its essential characteristics, is information-rich.

One of the main prerequisites for the active introduction of information technology in the hospitality industry is the use and development of the Internet.

Global internet traffic is projected to surpass all internet traffic in 2022 by 2016 . This explosive growth is due to a number of reasons. First of all, the COVID-19 pandemic has had a significant impact on Internet traffic, as a result of which most of the socio-economic activity has shifted to the Internet. As a result, Internet bandwidth increased by $35 \%$ in 2020, which showed the largest annual growth since 2013. Estimates indicate that almost $80 \%$ of total Internet traffic is associated with video views, use of social networks and [23].

According to estimates by the International Telecommunication Union (ITU), at the end of 2019, more than $51 \%$ of the world's population, or 4 billion people, used the Internet [24]. Moreover, over the past decade, these indicators have almost doubled (Table 1 ).

Table 1

World data on the number of Internet use

\begin{tabular}{|c|c|c|c|c|c|c|}
\hline \multirow[b]{2}{*}{ Years } & \multicolumn{3}{|c|}{ Number of Internet users } & \multicolumn{3}{|c|}{ Share of Internet users } \\
\hline & $\begin{array}{c}\text { value, } \\
\text { bil- } \\
\text { lion }\end{array}$ & $\begin{array}{l}\text { absolute } \\
\text { growth, } \\
\text { billion }\end{array}$ & $\begin{array}{c}\text { relative } \\
\text { growth, } \\
\%\end{array}$ & $\begin{array}{l}\text { value, \% of } \\
\text { the world } \\
\text { population }\end{array}$ & $\begin{array}{c}\text { absolute } \\
\text { growth, } \\
\%\end{array}$ & $\begin{array}{c}\text { relative } \\
\text { growth, } \\
\%\end{array}$ \\
\hline 2005 & 1.1 & $x$ & $x$ & 16.80 & $x$ & $x$ \\
\hline 2006 & 1.2 & 0.1 & 9.1 & 18.40 & 1.6 & 9.5 \\
\hline 2007 & 1.4 & 0.2 & 16.7 & 20.60 & 2.2 & 12.0 \\
\hline 2008 & 1.6 & 0.2 & 14.3 & 23.10 & 2.5 & 12.1 \\
\hline 2009 & 1.8 & 0.2 & 12.5 & 25.80 & 2.7 & 11.7 \\
\hline 2010 & 2.0 & 0.2 & 11.1 & 29.30 & 3.5 & 13.6 \\
\hline 2011 & 2.2 & 0.2 & 10.0 & 31.80 & 2.5 & 8.5 \\
\hline 2012 & 2.5 & 0.3 & 13.6 & 34.70 & 2.9 & 9.1 \\
\hline 2013 & 2.7 & 0.2 & 8.0 & 36.90 & 2.2 & 6.3 \\
\hline 2014 & 2.8 & 0.1 & 3.7 & 38.90 & 2 & 5.4 \\
\hline 2015 & 3.0 & 0.2 & 7.1 & 41.10 & 2.2 & 5.7 \\
\hline 2016 & 3.3 & 0.3 & 10.0 & 43.90 & 2.8 & 6.8 \\
\hline 2017 & 3.5 & 0.2 & 6.1 & 46.30 & 2.4 & 5.5 \\
\hline 2018 & 3.7 & 0.2 & 5.7 & 49.00 & 2.7 & 5.8 \\
\hline 2019 & 4.0 & 0.3 & 8.1 & 51.40 & 2.4 & 4.9 \\
\hline
\end{tabular}

Note: compiled according to [24]

Against the background of positive informational trends affecting the development of the hospitality industry, it is advisable to highlight negative trends - large disagreements and imbalances. Geographic surveys show uneven Internet access in different regions of the world. So, at the end of 2019, the maximum number of households with Internet access was recorded in European countries (85.0\%), which is significantly higher than in the world $(51.4 \%)$. The second place in terms of Internet access was occupied by the CIS countries $(76.4 \%)$, followed by the countries of North and South America (69.8\%), Arab countries (58.9\%), Asia and Oceania (53.4\%), respectively. The lowest level of household access to the Internet was observed in Africa $(14.3 \%)$ [24, 25].

In Ukraine, in $2019,77.7 \%$ of the population had access to the Internet, which is significantly higher than the global average and slightly lower than the European average [26]. As for the population of less developed countries, only $20 \%$ of the inhabitants use the Internet. For example, if in most developed 
countries of the world up to 8 out of 10 Internet users make online purchases, then in many least developed countries this indicator is less than 1 in 10. It is also advisable to note significant differences between rural and urban populations, different age categories, and also between men and women within the country $[23,24]$. cesses of enterprises in the hospitality industry, they change the final consumer of services. In this regard, an equally important information trend, both in the global and domestic hospitality industry, is the formation of the target consumer segment of tourists and travelers - millennials (generation $Y)$. At the present stage of development, the generation of millennials themselves is actively influencing the development main consumers of hospitality services are middle-aged people with a regular income of the middle level and above, and secondly, with developed information and communication skills and active use of digital technologies (Fig. 1).

So, in 2015 , a relatively new segment was formed on the
Information technologies affect not only the business proof the hospitality industry for objective reasons. Firstly, the

able imprint, radically changing the vectors of its development. According to this, the state of the global hospitality industry is influenced by individual consumer preferences, which are primarily associated with the emergence of new technological and marketing needs. In other words, the use of information and communication technologies (ICT) creates the basis for the emergence of new accommodation facilities, expansion of tourism and hotel services.

If the representatives of past generations perceived hotels only as a place where it is possible to spend the night, then in recent years, accommodation facilities have turned into real centers of activity. This is due to the high standards of placement through the use of ICT [30].

The impact of ICTs on the state of development of hospitality enterprises is at the heart of modern scientific and expert research. So, in order to develop further strategic directions of activity, Amadeus specialists studied and predicted the target portrait of the future tourist. So, the research results allow to identify 3 main types of tourists and travelers:

1. Cultural Purists - focused mainly on the cultural characteristics of the new location, tourist travel is considered as an opportunity to step aside from everyday life, explore a new culture, and get acquainted with the local flavor. This category of tourists is interested in new experiences, they are driven by the desire to learn new things.

2. Social Capital Seekers - focused on social recognition, actively publish their impressions on social networks. It is very important for this category of tourists to share their experience with others, which increases the significance of the trip. They structure their journey with the future online audience in mind.

3. Reward Hunters - reward oriented, seeking a return on investment, wanting to get the most out of the ride for their money. Their main idea is that they deserve better rest [31].

According to this study, Amadeus is hospitality market, called the "Digital Consumer" and emerged from generation $Y$, which is characterized by active involvement in the development of digital technologies. The representatives of generation $Y$ were influenced, first of all, by the development of information and communication networks (e-mail, instant messengers, video hosting and social networks). In this regard, enterprises in the hospitality industry are primarily focused on attracting this particular segment of consumers. Organizationally, research shows that Gen $Y$ value the speed, flexibility and efficiency of service, bookings of accommodation are carried out over the Internet, on average they check at least 10 sources before booking. This category of consumers has developed their own approach to the choice of a hotel under the influence of the information and communication environment, as well as certain features of the procedure for purchasing hotel services.

5. 2. Analysis of the types of information and communication technologies affecting the development of the hospitality industry

The transformation of the target portrait of the consumer of services in the hospitality industry made a noticeactively integrating ICT into its operations. Modern cognitive platforms make it possible to analyze human behavior directly in the process of communicating with him/her and draw operational conclusions. In particular, Amadeus Alita will listen to the client, take into account all the nuances of his/her request (management, type of trip, its duration and other factors) and display travel options suitable for this particular client on the travel agent's screen. The program differentiates intonation and can determine mood. If the client contacts again, "smart assistants" refer to the booking history and additionally analyze the client's benefits [32].

The types and tools of ICT that are actively being introduced at the present stage, accelerating the development of the hospitality industry, are summarized in Fig. 2.

According to the above classification, it seems expedient to systematize all the abundance of modern ICT into 3 groups: self-service technologies, data transmission and exchange technologies, and demand forecasting technologies. Certain types of ICT, due to their multifunctionality, can be attributed to several groups. 


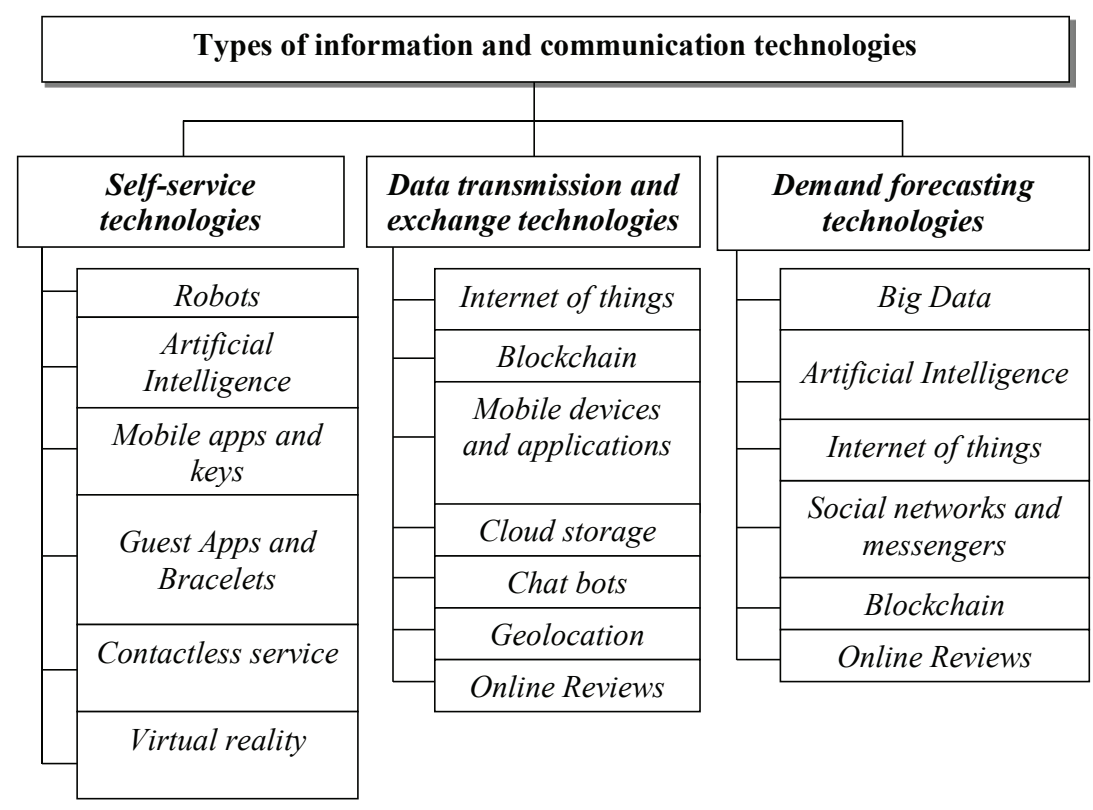

Fig. 2. Types of modern information and communication technologies in the hospitality industry

Note: compiled according to [30, 31,33, 34]

5. 3. Research of information and communication technologies for optimizing business processes in the hospitality sector

The allocation of certain types of ICT groups creates the basis for a more in-depth study of them, in particular, it seems appropriate to determine which ICTs are used to improve individual business processes of enterprises in the hospitality industry.

To this end, it is necessary to monitor the main business processes of providing hospitality services (Fig. 3).

The procedure for providing hospitality services consists of five business processes and is cyclical in nature. Moreover, the formation of each business process takes place on the basis of taking into account the needs of the client. If the customers are satisfied, then the hospitality service contains all the stages, and will also be repetitive; otherwise, the hospitality service cycle can be interrupted at any stage and hotels lose customers. In order to avoid these negative consequences and taking into account digital development trends in the hospitality sector, they are actively introducing ICT at every stage of service provision. Thus, in Table 2, it seems appropriate to expand the diagram of business processes in the hospitality industry with an indication of the ICT that optimize them.

As an example, it seems appropriate to consider the development of a specific enterprise in the hospitality industry in the context of the effective use of ICT, in particular, KViHotel (Budapest). KViHotel is fully computerized and is positioned as the first "smart hotel" in the world. Registration takes place through a special application in which guests choose their own rooms. At the same time, the smartphone performs the functions of an electronic key, an electronic concierge and the only control panel. There are practically no staff in the corridors of the hotel, and there is also no technical room. During your stay at the hotel, communication with the administrative and service personnel takes place through any convenient messenger. However, individual reviews from KViHotel guests indicate the need to develop "smart accommodation facilities", which are designed to optimize internal business processes and improve the quality of services. Lack of experience in using these ICTs requires immediate support, "live" contact. Thus, to improve efficiency at this hotel, it is important to focus on personalizing the user experience, streamlining business processes and creating guest experiences. As a result, additional value will be created for the client audience [37].

The use of ICT at all stages of the provision of hospitality services creates real preconditions for increasing the level of efficiency and service by accelerating the exchange of information between people and management subsystems. The experience of large hotel chains (Hilton, Hyatt, Sheraton, Holiday Inn, Courtyard, Hampton Inn, Mercure, Ramada, SHANGRI-LA ASIA, etc.) testifies to the active implementation of information and communication tools in almost all business processes. However, along with the positives, there are negative ones associated with high costs that are not affordable for small hospitality and accommodation companies.

Table 2

ICTs that optimize business processes and functions in the hospitality industry

\begin{tabular}{|c|c|c|}
\hline $\begin{array}{l}\text { Business } \\
\text { processes }\end{array}$ & $\begin{array}{l}\text { Business pro- } \\
\text { cess functions }\end{array}$ & ICT business optimization \\
\hline $\begin{array}{l}\text { 1. Pre-selec- } \\
\text { tion of the } \\
\text { service }\end{array}$ & $\begin{array}{l}\text { - marketing } \\
\text { and sales; } \\
\text { - booking; } \\
\text { - customer } \\
\text { loyalty }\end{array}$ & $\begin{array}{l}\text { ICT business process optimization, artificial intelligence, } \\
\text { booking systems, global distribution systems, hotel websites } \\
\text { and mobile apps, online travel agencies, aggregators, Google, } \\
\text { voice search and booking, hotel systems, room inventory, } \\
\text { booking forecasting, revenue and expense management, } \\
\text { rooms, inventory and revenue management practices in oth- } \\
\text { er areas of the hotel, pre-service, relationship management }\end{array}$ \\
\hline $\begin{array}{l}\text { 2. Arrival at } \\
\text { the hotel }\end{array}$ & $\begin{array}{l}\text { - check; } \\
\text { - luggage } \\
\text { delivery }\end{array}$ & $\begin{array}{l}\text { Property management systems, mobile apps, self-service } \\
\text { kiosks, keys and door unlocking systems, robotic luggage } \\
\text { trolleys }\end{array}$ \\
\hline $\begin{array}{l}\text { 3. Stay at the } \\
\text { hotel }\end{array}$ & \begin{tabular}{|c|} 
- guests \\
service; \\
- living room; \\
- hotel \\
amenities; \\
- cleaning and \\
maintenance \\
\end{tabular} & $\begin{array}{l}\text { Chatbots and programs, robotic delivery, concierge, smart } \\
\text { devices and the Internet of things, Property management } \\
\text { systems, Wi-Fi, in-room entertainment, smart mirrors, } \\
\text { mobile apps, point of sale systems and robotic delivery, } \\
\text { UV equipment, laundry control and uniforms, mainte- } \\
\text { nance and engineering, energy management, maintenance } \\
\text { sensors, preventive sensors } \\
\end{array}$ \\
\hline $\begin{array}{l}\text { 4. Departure } \\
\text { from the hotel }\end{array}$ & $\begin{array}{c}- \text { departure of } \\
\text { guests }\end{array}$ & $\begin{array}{l}\text { Property management systems, mobile apps, self-service } \\
\text { kiosks, robotic baggage collection }\end{array}$ \\
\hline $\begin{array}{l}\text { 5. Impressions } \\
\text { of staying at } \\
\text { the hotel }\end{array}$ & $\begin{array}{l}\text { - check-up } \\
\text { after stay; } \\
\text { - repeat guest }\end{array}$ & Guest satisfaction, image management, customer loyalty \\
\hline $\begin{array}{l}\text { Customer } \\
\text { needs }\end{array}$ & $\times$ & $\begin{array}{l}\text { Screening systems, tutorials and online resources, staffing, } \\
\text { biometric clocks, personal safety equipment, performance } \\
\text { sensors }\end{array}$ \\
\hline
\end{tabular}

Note: compiled according to [35,36] 


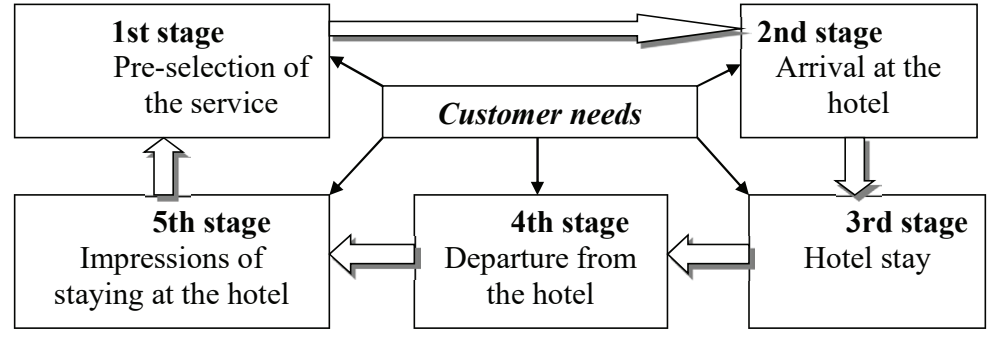

Fig. 3. Generalized diagram of business processes in the hospitality industry Note: compiled according to [35]

5. 4. Results of a study of the impact of information and communication technologies on the development strategy of enterprises in the hospitality industry

Despite the negative consequences of quarantine restrictions, the hospitality industry remains a unique sector with a multiplier effect, a powerful driver for the development of the real estate market, the service sector in general and the economies of countries as a whole [38].

Recent trends related to the liberal visa regime, as well as the differentiation of hospitality services, create the basis for the further development of the hospitality industry. With the help of ICT, hospitality enterprises satisfy the needs of customers in full in accordance with modern requirements and create prerequisites for the organizational and economic support of their further development by increasing profitability.

In this regard, it seems appropriate to establish the relationship between the volume of ICT output and the profitability of the objects of the Ukrainian hospitality industry, using the pair regression equation (Table 3 ).

According to the results of the regression analysis, it was found that $29.38 \%$ of the total variability in the profitability of objects of the domestic hospitality industry (parameter Y) is explained by changes in the volume of ICT output (parameter $\mathrm{X}$ ). In addition, it was found that an increase in the volume of ICT output by $1 \mathrm{mln}$. c.u. leads to an increase in the profits of temporary accommodation and catering enterprises by an average of $0.0186 \mathrm{mln}$. c.u.

A schematic reflection of the process of improving the organizational and economic support for the development of enterprises in the hospitality industry in the context of the use of ICT is shown in Fig. 4.

According to the above diagram, the process of improving the organizational and economic support for the development of enterprises in the hospitality industry in the context of the use of ICT includes three main stages. At the first stage, the analysis of internal and external factor conditions is carried out with the identification of opportunities for further development. At the second stage, the level of organizational and economic support for the development of information and communication technologies in the hospitality industry is assessed. To assess the components of organizational and economic support, it is necessary to use a system of quantitative characteristics. So, for example, to assess the level of organizational support, it is advisable to use the following criteria:

1) the amount of ICT used in the enterprise;

2) experience of using ICT, expressed in time intervals;

3) the number of clients loyal to the hospitality enterprise;

4) the share of business processes optimized using ICT in the total number;

5) proportion of personnel using ICT in the total headcount, etc.
In turn, the following indicators can be used to assess the level of economic security:

1) profitability or profitability;

2) the general level of investment costs;

3) expenses for the introduction of ICT;

4) the costs of training or advanced training of personnel;

5) the costs of automating business processes, etc.

All indicators should be calculated for a certain period of time, as well as standardized. After that, the significance of each of them can be established by the method of expert assessments and the integral indicator of the organizational and economic support for the development of ICT in the hospitality industry can be calculated. According to the value of the integral indicator, it becomes possible to establish a low, medium or high level of organizational and economic support, which gives grounds for choosing an appropriate development strategy (Table 4).

Table 3

The relationship between the volume of ICT output and the profitability of objects of the Ukrainian hospitality industry

\begin{tabular}{|c|c|c|}
\hline Years & $\begin{array}{l}\text { The volume of products } \\
\text { (goods, services) by informa- } \\
\text { tion and telecommunication } \\
\text { enterprises, mln. c.u. }(X)\end{array}$ & $\begin{array}{l}\text { Net profit (loss) of tempo- } \\
\text { rary accommodation and } \\
\text { catering enterprises, mln. } \\
\text { c.u. }(Y)\end{array}$ \\
\hline 2015 & $5,495.336$ & -286.446 \\
\hline 2016 & $6,320.379$ & -72.932 \\
\hline 2017 & $7,793.146$ & 63.188 \\
\hline 2018 & $9,892.160$ & 84.906 \\
\hline 2019 & $14,154.259$ & 179.244 \\
\hline \multicolumn{3}{|c|}{ Regression equation parameters: } \\
\hline \multicolumn{2}{|r|}{ Regression equation $\left(Y_{X}\right)$} & $Y_{X}=0.0186 \mathrm{X}-140.315$ \\
\hline \multicolumn{2}{|c|}{ Correlation coefficient $\left(r_{x y}\right)$} & 0.542 \\
\hline \multicolumn{2}{|c|}{ Average coefficient of elasticity $(E)$} & -25.276 \\
\hline \multicolumn{2}{|c|}{ Determination coefficient $\left(\mathrm{R}^{2}\right)$} & 0.2938 \\
\hline \multicolumn{2}{|c|}{ Average approximation error $(A)$} & $3.2 \%$ \\
\hline
\end{tabular}

Note: compiled according to [39, 40]

For a better understanding of the process of implementing the strategies given in Table 4, it is advisable to present a classification of organizational structures that are typical for enterprises in the hospitality industry, depending on the level of ICT development. In this regard, three types of organizational structures can be distinguished:

1. Flat structure - characteristic of a low level of ICT development, the main role in the implementation of the strategy belongs to the leaders.

2. Divisional - typical for the average level of ICT development, the main role in the implementation of the strategy belongs to the employees of the hospitality industry.

3. Adhocratic - typical for a high level of ICT development, the main role in the implementation of the strategy belongs to the consumers of the hospitality industry, decisions are made by mutual agreement.

The effectiveness of the implementation of the proposed strategies, first of all, will depend on the experience of managers and employees of enterprises in the hospitality industry and only indirectly on consumers. The proposed strategies and directions are universal and can be used in various enterprises of the hospitality industry. 


\begin{tabular}{|c|c|c|c|}
\hline \multicolumn{4}{|c|}{ Analysis of the prerequisites for the development of enterprises in the hospitality industry } \\
\hline $\begin{array}{l}\text { Analysis of resource } \\
\text { opportunities }\end{array}$ & \multicolumn{2}{|c|}{ Analysis of positive trends } & Analysis of negative trends \\
\hline & & & \\
\hline \multicolumn{4}{|c|}{$\begin{array}{l}\text { Assessment of the level of organizational and economic support for the development of } \\
\text { information and communication technologies in the hospitality industry }\end{array}$} \\
\hline \multicolumn{2}{|c|}{ Organizational support assessment } & \multicolumn{2}{|c|}{ Economic support assessment } \\
\hline & & & \\
\hline \multicolumn{4}{|c|}{$\begin{array}{c}\text { Choosing a strategy and developing directions for increasing the level of development of } \\
\text { information and communication technologies at different levels }\end{array}$} \\
\hline
\end{tabular}

Fig. 4. The process of improving the organizational and economic support for the development of enterprises in the hospitality industry in the context of the use of information and communication technologies

Strategies and directions for increasing the level of development of information and communication technologies in the hospitality industry

\begin{tabular}{|c|c|c|c|}
\hline \multirow{2}{*}{$\begin{array}{l}\text { The level of develop- } \\
\text { ment of information } \\
\text { and communication } \\
\text { technologies }\end{array}$} & \multicolumn{3}{|c|}{ Implementation level } \\
\hline & leaders & $\begin{array}{l}\text { hospitality industry } \\
\text { workers }\end{array}$ & $\begin{array}{l}\text { hospitality industry } \\
\text { consumers }\end{array}$ \\
\hline \multirow[b]{2}{*}{ Low } & \multicolumn{3}{|c|}{ Information expansion strategy } \\
\hline & $\begin{array}{c}\text { Awareness of the need for } \\
\text { technical re-equipment } \\
\text { of the main business } \\
\text { processes }\end{array}$ & $\begin{array}{l}\text { Active involvement in } \\
\text { learning and acquisition of } \\
\text { information and communi- } \\
\text { cation skills }\end{array}$ & $\begin{array}{l}\text { Implementation } \\
\text { of promotions, } \\
\text { discounts and other } \\
\text { loyalty programs }\end{array}$ \\
\hline \multirow[b]{2}{*}{ Average } & \multicolumn{3}{|c|}{ Improvement strategy } \\
\hline & $\begin{array}{c}\text { Technical re-equipment } \\
\text { of the main business } \\
\text { processes }\end{array}$ & $\begin{array}{c}\text { Continuous improvement } \\
\text { of information and com- } \\
\text { munication skills }\end{array}$ & $\begin{array}{l}\text { Support for a high } \\
\text { level of loyalty }\end{array}$ \\
\hline \multirow[b]{2}{*}{ High } & \multicolumn{3}{|c|}{ Content strategy and further development } \\
\hline & $\begin{array}{c}\text { Research of modern } \\
\text { trends in the development } \\
\text { of ICT }\end{array}$ & $\begin{array}{l}\text { Readiness to master new } \\
\text { ICT tools }\end{array}$ & $\begin{array}{l}\text { Maintaining a high } \\
\text { level of loyalty and } \\
\text { development of new } \\
\text { target segments }\end{array}$ \\
\hline
\end{tabular}

\section{Discussion of the results of the study of the influence of information and communication technologies on the effectiveness of the development of enterprises in the hospitality industry}

Analysis of global information trends in the development of the hospitality industry proves that the main prerequisite for the active implementation of ICT is the Internet. The development of the Internet creates the basis for increasing the level of digital literacy of the population, ensures the acquisition and improvement of information and communication skills. Moreover, the problem of uneven provision of information resources between countries of the world, as well as individual categories of the population within countries, arises.

The study made it possible to single out a target portrait of a consumer of services in the hospitality industry based on [3-5,27]. Unlike [20], which singles out millennials and post millennials as a target audience, it is substantiated that it
Table 4

is the first category that has a more significant impact on the development of the hospitality industry. It is to millennials, who are characterized by a high level of digital development, that hoteliers are directing the modern range of information and communication tools because there is a need for them.

The use of an integrated approach to ICT research, in contrast to many studies, where attention is focused on the study of a specific ICT tool, gives grounds to assert the need for further development. The variety of existing ICTs has been generalized and systematized according to several criteria. However, the rapid development of information technology and dynamic changes in the hospitality industry require constant attention to new ICT tools. In this connection, the proposed classification groups can be expanded.

Analysis of existing trends has proved the need to identify the stages of the process of improving the organizational and economic support for the development of enterprises in the hospitality industry in the context of the use of ICT. The implementation of sequential steps (Fig. 4) creates the prerequisites for the formation of strategies for the development of enterprises in the hospitality industry, depending on the level of ICT use (Table 4). At the same time, the proposed directions for improving information and communication skills at different levels that ensure the implementation of strategies are quite logical.

The obtained scientific results of increasing the level of use of information and communication technologies constitute the scientific and methodological basis for ensuring the effective development of enterprises in the hospitality industry. In turn, other types of economic activity correlate with the development of the hospitality industry. This gives grounds to assert that this study is important for the development of the economy as a whole.

The practical significance of the research carried out is confirmed by the classification of modern ICTs carried out according to the cycle of providing the ambassador in hospitality. The main business processes and functions are highlighted, as well as tools that are actively used at each stage.

Analyzing the content of the proposed provisions, it is advisable to note that the study is aimed at the development of hotels, while focusing on ICT used in hotel chains. Along with this, the hospitality industry consists of travel compa- 
nies, catering establishments, which we are talking about indirectly. This indicates the relative limitations of scientific and methodological development.

The development of further research initiated by this publication is to further deepen the theoretical groundwork for the development of the hospitality industry through the use of ICT. Special attention is required to implement strategies for the development of enterprises in the hospitality industry, taking into account national and regional specifics and depending on the specific conditions of activity. This, in turn, will affect the possibilities of using one or another ICT tool.

\section{Conclusions}

1. It is established that the development of the hospitality industry is directly dependent on the level of digitalization of the economy and the informatization of society. It is proved that the main prerequisite for activating the studied process is the level of digital literacy of the population and the possession of information and communication skills. In this regard, to assess them, an indicator was used that characterizes the population's access to the Internet, the analysis of which highlighted positive and negative trends. A target portrait of a consumer of hospitality services is proposed by constructing a scheme for the transformational transformation of consumers of hospitality services in the $21^{\text {st }}$ century. It is substantiated that at the present stage a "Digital consumer" has emerged, which has emerged from generation Y, using an approach to the choice of hotel services under the influence of information and communication technologies.

2. The types and tools of information and communication technologies, which are actively introduced at the present stage, are systematized, accelerating the development of the hospitality industry. It is proved that the use of ICTs creates the basis for the emergence of new accommodation facilities, expansion of tourism and hotel services. Based on the analysis of individual consumer preferences, three groups of tourists were identified, the motives of which are directly related to the emergence of new technological and marketing needs. It is established that information technologies affect not only the business processes of enterprises in the hospitality industry, they change the final consumer of services.

3 . The main stages of the cycle of providing hospitality services are highlighted and the nature of its cyclical nature is substantiated. The necessity of using information and communication technologies at all stages of the provision of hospitality services is established. The tools of information and communication technologies are systematized, depending on the business processes and functions of the hospitality service delivery cycle. It is proved that the coverage of information and communication technologies of all business processes creates real prerequisites for increasing the level of efficiency and service by accelerating the exchange of information between people and management subsystems.

4. The results obtained provided the basis for a schematic reflection of the process of improving the organizational and economic support for the development of enterprises in the hospitality industry in the context of the use of information and communication technologies. It is established that the level of organizational and economic support for the development of information and communication technologies in the hospitality industry (low, medium, high) gives grounds for choosing an appropriate development strategy. It is proved that only under the condition of coordinated activities of managers, personnel and the use of effective means of influencing consumers of hospitality industry services, success in the implementation of the proposed strategies will be ensured.

\section{References}

1. Morozov, M. A., Morozova, N. S. (2016). Attractive Tourist Destinations as a Factor of its Development. Journal of Environmental Management and Tourism, 7 (1), 105-112. Available at: https://journals.aserspublishing.eu/jemt/article/view/310

2. Vetitnev, A. M., Kovalenko, V. V., Kovalenko, V. V. (2019). Informatsionno-kommunikatsionnye tekhnologii v turizme. Moscow: Izdatel'stvo Yurayt, 340.

3. Gonzalez, R., Gasco, J., Llopis, J. (2019). ICTs in hotel management: a research review. International Journal of Contemporary Hospitality Management, 31 (9), 3583-3609. doi: https://doi.org/10.1108/ijchm-07-2017-0470

4. Mandić, A., Garbin Praničević, D. (2019). Progress on the role of ICTs in establishing destination appeal. Journal of Hospitality and Tourism Technology, 10 (4), 791-813. doi: https://doi.org/10.1108/jhtt-06-2018-0047

5. Hua, N. (2020). Do information technology (IT) capabilities affect hotel competitiveness? Journal of Hospitality and Tourism Technology, 11 (3), 447-460. doi: https://doi.org/10.1108/jhtt-02-2020-0036

6. Ruel, H., Njoku, E. (2020). AI redefining the hospitality industry. Journal of Tourism Futures, 7 (1), 53-66. doi: https:// doi.org/10.1108/jtf-03-2020-0032

7. Johnson, R. D., Stone, D. L., Lukaszewski, K. M. (2020). The benefits of eHRM and AI for talent acquisition. Journal of Tourism Futures, 7 (1), 40-52. doi: https://doi.org/10.1108/jtf-02-2020-0013

8. McCartney, G., McCartney, A. (2020). Rise of the machines: towards a conceptual service-robot research framework for the hospitality and tourism industry. International Journal of Contemporary Hospitality Management, 32 (12), 3835-3851. doi: https:// doi.org/10.1108/ijchm-05-2020-0450

9. Navio-Marco, J., Ruiz-Gómez, L. M., Sevilla-Sevilla, C. (2019). Progress in wireless technologies in hospitality and tourism. Journal of Hospitality and Tourism Technology, 10 (4), 587-599. doi: https://doi.org/10.1108/jhtt-07-2018-0061

10. Zhang, Y. (2020). A Big-Data Analysis of Public Perceptions of Service Robots Amid Covid-19. Advances in Hospitality and Tourism Research (AHTR). doi: https://doi.org/10.30519/ahtr.799210

11. Lee, W., Ko, Y. D. (2021). Operation policy of multi-capacity logistic robots in hotel industry. International Journal of Contemporary Hospitality Management, 33 (5), 1482-1506. doi: https://doi.org/10.1108/ijchm-05-2020-0372

12. Zhong, Y., Shapoval, V., Busser, J. (2021). The role of parasocial relationship in social media marketing: testing a model among baby boomers. International Journal of Contemporary Hospitality Management, 33 (5), 1870-1891. doi: https://doi.org/10.1108/ijchm-08-2020-0873 
13. Kapoor, P. S., Balaji, M. S., Jiang, Y. (2021). Effectiveness of sustainability communication on social media: role of message appeal and message source. International Journal of Contemporary Hospitality Management, 33 (3), 949-972. doi: https://doi.org/10.1108/ ijchm-09-2020-0974

14. Paül i Agustí, D. (2021). Mapping gender in tourist behaviour based on instagram. Journal of Outdoor Recreation and Tourism, 35, 100381. doi: https://doi.org/10.1016/j.jort.2021.100381

15. Dharmesti, M., Dharmesti, T. R. S., Kuhne, S., Thaichon, P. (2019). Understanding online shopping behaviours and purchase intentions amongst millennials. Young Consumers, 22 (1), 152-167. doi: https://doi.org/10.1108/yc-12-2018-0922

16. Lata, S., Rana, K. (2021). What are the determinants of consumers' online reviews adoption for hotel bookings: a structural equation modelling approach. Enlightening tourism: a pathmaking journal, 11 (1), 171-193. doi: https://doi.org/10.33776/et.v11i1.5354

17. Hwang, Y., Wang, X., Paşamehmetog̉lu, A. (2021). Customer online reviews and hospitality employees' helping behavior: moderating roles of self-efficacy and moral identity. International Journal of Contemporary Hospitality Management, 33 (5), 1461-1481. doi: https://doi.org/10.1108/ijchm-01-2021-0056

18. Lin, A., Ma, E., Chen, B. T. (2019). The effect of interactive IT table service on consumer's revisit intention. Advances in Hospitality and Tourism Research (AHTR), 7 (1), 124-136. doi: https://doi.org/10.30519/ahtr.527022

19. Mercan, S., Cain, L., Akkaya, K., Cebe, M., Uluagac, S., Alonso, M., Cobanoglu, C. (2020). Improving the service industry with hyper-connectivity: IoT in hospitality. International Journal of Contemporary Hospitality Management, 33 (1), 243-262. doi: https://doi.org/10.1108/ijchm-06-2020-0621

20. Monaco, S. (2018). Tourism and the new generations: emerging trends and social implications in Italy. Journal of Tourism Futures, 4 (1), 7-15. doi: https://doi.org/10.1108/jtf-12-2017-0053

21. Lei, S. I., Wang, D., Law, R. (2019). Hoteliers' service design for mobile-based value co-creation. International Journal of Contemporary Hospitality Management, 31 (11), 4338-4356. doi: https://doi.org/10.1108/ijchm-03-2018-0249

22. Wan Daud, W. A. A., Abdul Ghani, M. T., Amiruddin, A. Z., Abdul Ghani, K., Abdul Rahman, A. (2021). The usability of i-Suyyah: a mobile tourism application for Arab tourists in Malaysia. Enlightening Tourism. A Pathmaking Journal, 11 (1), 263. doi: https://doi.org/ 10.33776/et.v11i1.5090

23. Doklad o tsifrovoy ekonomike: obzor (2021). Organizatsiya Obedinennyh Natsiy. Available at: https://unctad.org/system/files/officialdocument/der2021_overview_ru.pdf

24. Statistics (2021). International Telecommunication Union. Available at: https://www.itu.int/en/ITU-D/Statistics/Pages/stat/default.aspx

25. Morozov, M. A., Morozova, N. S. (2020). Innovative trends of the development of tourism and hotel business in the conditions of digitalization. Estestvenno-gumanitarnye issledovaniya, 28 (2), 196-202. doi: https://doi.org/10.24411/2309-4788-2020-10100

26. Dostup domohospodarstv Ukrainy do Internetu u 2019 rotsi: Statystychnyi zbirnyk (2020). Kyiv: Derzhavna sluzhba statystyky Ukrainy, 77. Available at: https://ukrstat.org/uk/druk/publicat/kat_u/2020/zb/07/zb_dd_in19.pdf

27. Myronova, N. (2020). Bumery, milenialy, pokolinnia Z - khto tse? Rozbyraiemos u teorii. Ukrainska pravda. Available at: https://life.pravda.com.ua/society/2020/02/9/239843/

28. Tsyfrova hramotnist naselennia Ukrainy. Available at: https://osvita.diia.gov.ua/research

29. Semenova, L. V., Klimova, T. B. (2018). World hotel industry: modern trends. Researh Result. Technology Business and Service, 4 (4), 13-24. Available at: http://rrbusiness.ru/media/business/2018/4/4-42018-14-25.pdf

30. Trendy gostinichnyh tekhnologiy 2021 (2020). Available at:https://welcometimes.ru/opinions/trendy-gostinichnyh-tehnologiy-2021

31. Tarasenko, E. V., Rozanova, T. P., Ilina, E. L., Kosheleva, A. I., Latkin, A. N. (2021). Transformation of the International Hospitality Industry in the COVID-19 Era: New Risks and Opportunities on the Example of Hotel Groups. Regional economy and management: electronic scientific journal, 1 (65). doi: https://doi.org/10.24412/1999-2645-2021-165-12

32. Amadeus Beratungsassistentin ALITA unterstützt Kundengespräche durch automatische Reisevorschläge. Available at: https:// amadeus.com/de/insights/pressemitteilung/amadeus-beratungsassistentin-alita-unterstuetzt-kundengespraeche-durchautomatische-reisevorschlaege

33. Driving Hospitality Innovation - industry report. Available at: https://hospitalityinsights.ehl.edu/industry-report-hospitality-innovation

34. Hillmann, S., Rosenkranz, N. Is blockchain the solution to the OTA challenge or is it merely a silver bullet hope? Available at: https:// hospitalityinsights.ehl.edu/blockchain-solution-ota-challenge

35. Stringam, B. B., Gerdes, J. H.; Cobanoglu, C., Dogan, S., Berezina, K., Collins, G. (Eds.) (2021). Hotel and guest room technology. Hospitality \& Tourism Information Technology, 1-60. doi: https://www.doi.org/10.5038/9781732127593

36. Bacik, R., Kmeco, L., Fedorko, R., Olearova, M., Rigelsky, M. (2019). Marketing Instrument of Improving Hotel Management Service: Evidence of Visegrad Group Countries. Marketing and Management of Innovations, 208-220. doi: https://doi.org/10.21272/mmi.2019.1-17

37. Digital-oteli: vchera, segodnya, zavtra... i na samom dele (2019). Available at: https://welcometimes.ru/opinions/digital-oteli-vcherasegodnya-zavtra-i-na-samom-dele

38. Bereschak, V. (2020). Obzor rynka oteley: chto proiskhodit s gostinitsami v Ukraine. Available at: https://thepage.ua/real-estate/ obzor-rynka-otelej-chto-proishodit-s-gostinicami-v-ukraine

39. Activity of business entities (2020). Kyiv: State Statistics Service of Ukraine, 151. Available at: http://www.ukrstat.gov.ua/druk/ publicat/kat_u/2020/zb/11/DSG_2019.pdf

40. Kursy Natsionalnoho banku Ukrainy: arkhiv valiutnykh kursiv (2021). Available at: https://index.minfin.com.ua/ua/exchange/ archive/nbu/ 